\title{
Frequency of peripheral neuropathy in newly diagnosed cases of type II diabetes mellitus.
}

1. MBBS, FCPS

Assistant Professor Medicine

Avicenna Medical \& Dental College, Lahore.

2. MBBS, FCPS

Associate Professor Medicine

Azhra Naheed Medical College,

Lahore.

3. MBBS, FCPS

Professor Medicine

Avicenna Medical \& Dental College,

Lahore.

4. MBBS, FCPS

Associate Professor Medicine

$\mathrm{CMH}$ Lahore.

5. MBBS, FCPS

Assistant Professor Medicine

Social Security Teaching Hospital,

Lahore.

6. MBBS, FCPS

Assistant Professor Medicine

Bolan University of Medical and

Health Sciences, Quetta.

\author{
Altaf Ahmad Yar' ${ }^{1}$, Munaza Javed², Muzamul Shahzad ${ }^{3}$, Javed Iqbal ${ }^{4}$, Muhammad Imran Aslam ${ }^{5}$, \\ Zafar Ahmad Khan ${ }^{6}$
}

ABSTRACT... Objective: The aim of this study is to determine the frequency of peripheral neuropathy in newly diagnosed cases of type II diabetes mellitus. Study Design: Cross Sectional Study. Setting: Department of Medicine at Avicenna Medical \& Dental College, Lahore. Period: $1^{\text {st }}$ February 2020 to $31^{\text {st }}$ July 2020. Material \& Methods: One hundred and twenty newly diagnosed patients of type 2 diabetes mellitus were enrolled in this study. Patients detailed demographically recorded after getting written consent. Patients were diagnosed for the duration of 4-weeks and calculated fasting blood sugar (FBS) of $\geq 126 \mathrm{mg} / \mathrm{dl}$, and Random Blood Sugar (RBS) of $\geq 200 \mathrm{mg} / \mathrm{dl}$ or $\mathrm{HbA} 1 \mathrm{c} \leq 6.5$. Results: Seventy $(58.3 \%)$ were males and rest $50(41.7 \%)$ were females with mean age $37.15 \pm 10.91$ years. Mean body mass index of the patients was $22.48 \pm 3.66 \mathrm{~kg} / \mathrm{m} 2$. Forty two $(35 \%)$ patients had symptoms of peripheral neuropathy while that patient's who did not have any symptom was 78 (65\%). Same symptoms were observed within 4-weeks and we noticed that 23 (19.2\%) patients showed peripheral neuropathy and rest 97 (80.8\%) patients did not have any symptoms. Conclusion: The frequency of peripheral neuropathy is higher in early stages of type II diabetes mellitus and its frequency can be reduced to diagnose within a month.

Correspondence Address:

Dr. Altaf Ahmad Yar

Department of Medicine

Avicenna Medical \& Dental College,

Lahore.

aayar75@yahoo.com

Key words: Diabetes Mellitus, Glucose, Metabolic Disorder, Peripheral Neuropathy.

Article received on:

$12 / 11 / 2020$

Accepted for publication:

23/05/2021

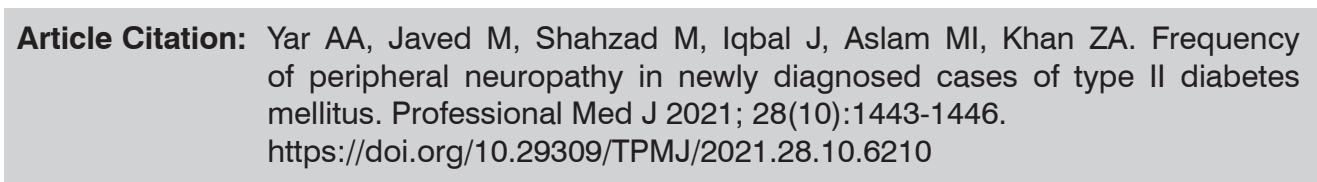

\section{INTRODUCTION}

Diabetic mellitus (DM) is a severe metabolic disorder that affects to the world's growing economic. As a cost for urbanisation, the overall diabetes situation in 2017 according to IDF estimates, shows there are 425 million diabetes adults and 352 million glucose deficient adults in the world. ${ }^{1}$ In Jordan the alarming rates in obesity, growth in the population, transition to nutrition, and a major challenge..$^{2,3}$

WHO's figures suggest that the highest overweight and obesity rates in Egypt, Bahrain, Jordan, Kuwait, Saudi Arabia and the United Arab Emirates have been in 16 countries in the Eastern Mediterranean. ${ }^{4}$ Approximately $50 \%$ are expected to develop neuropathy based on the length of disease and the diabetic regulation. 5,6 Multifactorial pathogenesis of peripheral diabetic neuropathy. The DPN can be categorized as widespread symmetry polyneuropathies and focus / multipocal neuropathies, while polyol pathway, advanced glycemic end products and oxidative stress and chronic hyperglycaemia have an important position. Symmetrical, distal sensorimotor polyneuropathy (DPN) is the most prevalent form of diabetes neuropathy. ${ }^{7}$ This is around $75 \%$ of diabetic neuropathy. ${ }^{8}$

There are no local data available regarding peripheral neuropathy prevalence in diabetic patients at the time of diagnosis; however, 7.5 percent of the patients at the time of diagnosis are reported to have neuropathy. ${ }^{9}$ Therefore, peripheral neuropathy is one of the key aspects when diabetic patients are advised and early detection of primary care is essential for initiation of the disease.

In this research we aimed to determine the frequency of peripheral neuropathy in newly diagnosed cases of type II diabetes mellitus. 


\section{MATERIAL \& METHODS}

This cross-sectional study was conducted at Avicenna Medical \& Dental College, Lahore during the period of $1^{\text {st }}$ February 2020 to $31^{\text {st }}$ July 2020 with IRB approval letter No. SSTH-4637 dated 1911-2020. A total of 120 patients of both genders with ages 25 to 60 years presented with peripheral neuropathy among newly diagnosed diabetes were enrolled. Patient detailed demographics including age, sex, residence and body mass index were recorded after taking written consent. Patients who had peripheral neuropathy due to other disease i.e. autoimmune, drugs, renal failure, liver disease, leprosy and malignancy were excluded from this study. All the patients were examined clinically and electrophysiological method was used (only for a purpose if required) within a month. Three types of muscles (sample) were tested to examine impression of neuropathy. Complete patients were examined to calculate fasting blood sugar (FBS) of $\geq 126 \mathrm{mg} / \mathrm{dl}$, and Random Blood Sugar (RBS) of $\geq 200 \mathrm{mg} / \mathrm{dl}$ or $\mathrm{HbA1c} \leq 6.5$. Chi square test was performed to know the prevalence of duration of symptoms. All data was analyzed by SPSS 24.0

\section{RESULTS}

There were $70(58.2 \%)$ males while $50(41.8 \%)$ were females with mean age $37.15 \pm 10.91$ years. Mean BMI was $22.48 \pm 3.66 \mathrm{~kg} / \mathrm{m}^{2}$ (Table-l). At start, we observed that the $42(35 \%)$ patients had symptoms of peripheral neuropathy while that patient's who did not have any symptom was 78 (65\%). After continuously examination within a month, we observed the prevalence of symptoms $23(19.2 \%)$ patients showed peripheral neuropathy as compared to these 97 (80.8\%) patients did not show any symptoms (Table-II). Regular examination showed results that out of 23 patients, 8 (34.8\%) patients showed peripheral neuropathy and the remaining 15 (65.2\%) patients did not show any symptoms. That 97 $(80.8 \%)$ patients who did not show symptoms at start, after further analysis $34(35.05 \%)$ showed symptoms and 63 (64.95\%) were not symptomatic (Table-III). We observed that the majority of the patients $45.8 \%$ were in $5^{\text {th }}$ decade of peripheral neuropathy, $29.2 \%$ were in $4^{\text {th }}$ decade and rest of $25 \%$ were in $6^{\text {th }}$ decade of diabetic peripheral neuropathy.

\begin{tabular}{|c|c|}
\hline Variable & No. (\%) \\
\hline Mean age (years) & $37.15 \pm 10.91$ \\
\hline Mean BMI $(\mathrm{Kg} / \mathrm{m})$ & $22.48 \pm 3.66$ \\
\hline \multicolumn{2}{|l|}{ Gender } \\
\hline Male & $70(58.2 \%)$ \\
\hline Female & $50(41.8 \%)$ \\
\hline \multicolumn{2}{|c|}{ Table-I. Baseline detail of all the patients. } \\
\hline Peripheral Neuropathy & No. (\%) \\
\hline \multicolumn{2}{|l|}{ Beginning } \\
\hline Yes & $42(35.0 \%)$ \\
\hline No & $78(65.0 \%)$ \\
\hline \multicolumn{2}{|l|}{ After 4-weeks } \\
\hline Yes & $23(19.2 \%)$ \\
\hline No & $97(80.8 \%)$ \\
\hline \multicolumn{2}{|c|}{ Table-II. Frequency of peripheral neuropathy. } \\
\hline Variable & No. (\%) \\
\hline \multicolumn{2}{|c|}{ Peripheral Neuropathy $(n=23)$} \\
\hline Yes & $8(34.8 \%)$ \\
\hline No & $15(65.2 \%)$ \\
\hline \multicolumn{2}{|c|}{ Non- Peripheral Neuropathy $(n=97)$} \\
\hline Yes & 34 (35.05\%) \\
\hline No & $63(64.05 \%)$ \\
\hline
\end{tabular}

\section{DISCUSSION}

Diabetic neuropathies are heterogeneous diseases that affect the multiple components of the patient's nervous system. It is the most predominant complication of diabetes mellitus. Nerve complications can occur in patients with diabetes mellitus at any time, but longer, higher risk. It has been estimated that $50 \%$ of diabetic patients are neuropathic, but not all neuropathic patients have symptoms. ${ }^{10}$ This study found that in $45(35 \%)$ patients, the symptoms of type II Diabetes Mellitus peripheral neuropathy were the same as those of Lakhiar. ${ }^{11}$ The variations between our various trials and our prevalence of peripheral diabetic neuropathy can be explained by the clinical and electrophysiological studies in our research, while other neuropathic studies in Wunderlich et $\mathrm{al}^{10}$, which is close to the findings of our study, showed 8 percent of type 2 diabetes 
at diagnosis.

The hypothesis that metabolism and obesity are risk factors for DPN is supported by current evidence. Nerve damage mechanisms suggested include extracellular protein glycation, a deposition of fats, oxidative stress, defective mitochondrial and counter-regulatory pathways to metabolising chronic inflammation. ${ }^{12,13}$ The restrictions are a multi-section design that could not determine the longer-term effects of DPN risk factors for glycemic regulation. Kestev et al ${ }^{14}$ have shown that insulin use among newly diagnosed diabetics in Germany and Great Britain is one of the highest risk factors for DPN.

Previous studies have shown clearly that diabetic patients suffering from other diseases are more likely to develop diabetic neuropathy including the degree of hypertension, dyslipidemia, insulin resistance, obesity, cigarette smoking and alcoholic consumption. The risk of diabetic neuropathy is correlated with a variety of modifiable and non-modifiable risk factors. ${ }^{15-21}$

Our study is a large-scale clinical study, so that our findings will relate to people in the population receiving treatment. In addition, initial steps should be taken to avoid DPN from progressing and postpone the development of such a deteriorating complication in terms of lifestyle and behavioural improvements such as balanced food habits and exercises.

\section{CONCLUSION}

The symptoms of peripheral neuropathy were present in $35 \%$ patients and there is need to diagnose at its earliest stage to reduce prevalence. Copyright@ 23 May, 2021.

\section{REFERENCES}

1. International Diabetes Federation (IDF). IDF Diabetes Atlas 8th ed. 2017

2. Ajlouni K, Khader YS, Batieha A, Ajlouni H, El-Khateeb $M$. An increase in prevalence of diabetes mellitus in Jordan over 10 years. J Diabetes Complicat 2008; 22:317-24.
3. Khader Y, Batieha A, Ajlouni H, El-Khateeb M, Ajlouni K. Obesity in Jordan: Prevalence, associated factors, comorbidities, and change in prevalence over ten years. Metab Syndr Relat Disord 2008; 6(2):113-20.

4. World Health Organization. http://www.who.int/ topics/ obesity/en/. Accessed 22 Jan 2018.

5. Dyck PJ, Kratz KM, Karnes JL, Litchy WJ, Klein R, Pach JM. The prevalence by staged severity of various types of diabetic neuropathy, retinopathy, and nephropathy in a population-based cohort: The Rochester Diabetic Neuropathy Study. Neurology 1993; 43(4):817-24.

6. Bild DE, Selby JV, Sinnock P, Browner WS, Braveman $P$, Showstack JA. Lower-extremity amputation in people with diabetes. Epidemiology and prevention. Diabetes Care 1989; 12(1):24-31.

7. Jasik M. Therapy of diabetic neuropathy. Przegl Lek 2003; 60:167-9.

8. Pastore C, Izura V, Geijo-Barrientos E, Dominguez JR. A comparison of electrophysiological tests for the early diagnosis of diabetic neuropathy. Muscle Nerve 1999; 22:1667-73.

9. Lin HC. Diabetic neuropathy. Medscape Reference [On-line]. 2011.

10. Wunderlich RP, Peters EJ, et al. Pathophysiology and treatment of painful diabetic neuropathy of lower extremity. South Med J 1998; 91:894-8

11. Lakhiar AM, Shahbaz N, Naila; Bughio AH, Prakash J. Frequency of peripheral neuropathy in newly diagnosed patients of diabetes mellitus iion clinical and electrophysiological basis. Pak J Neurol Sci 2014; 9(4): 9.

12. Callaghan B, Feldman E. The metabolic syndrome and neuropathy: Therapeutic challenges and opportunities. Ann Neurol 2013; 74:397-403.

13. Smith AG, Singleton JR. Obesity and hyperlipidemia are risk factors for early diabetic neuropathy. J Diabetes Complicat 2013; 27:436-42.

14. Kostev K, Jockwig A, Hallwachs A, Rathmann W. Prevalence and risk factors of neuropathy in newly diagnosed type 2 diabetes in primary care practices: $A$ retrospective database analysis in Germany and UK. Prim Care Diabetes 2014; 8:250-5.

15. Oh TJ, Lee J-E, Choi SH, et al. Association between body fat and diabetic peripheral neuropathy in middle-aged adults with type 2 diabetes mellitus: A preliminary report. J Obes Metab Syndr 2019, 28:1127 . 
16. Mathiyalagen $P$, Kanagasabapathy $S$, Kadar $Z$, et al. Prevalence and Determinants of Peripheral Neuropathy Among Adult Type II Diabetes Mellitus Patients Attending a Non-communicable Disease Clinic in Rural South India. Cureus 2021; 13(6): e15493.

17. Abdissa D. Prevalence and determinants of peripheral neuropathy among type 2 adult diabetes patients attending Jimma University Medical Center, Southwest Ethiopia, 2019, an institutionalbased cross-sectional study. J Diabetes Res 2020; 2020:4205283.

18. Jember G, Melsew YA, Fisseha B, Sany K, Gelaw AY, Janakiraman $B$. Peripheral sensory neuropathy and associated factors among adult diabetes mellitus patients in Bahr Dar, Ethiopia. J Diabetes Metab Disord 2017; 16(1): 1-8.
19. Yeboah K, Puplampu P, Boima V, Antwi DA, Gyan B, Amoah AGB. Peripheral sensory neuropathy in type 2 diabetes patients: A case control study in Accra, Ghana. J Clin Translational Endocrinol 2016; 5: 26-31.

20. Khawaja N, Abu-Shennar J, Saleh M, Dahbour SS, Khader YS, Ajlouni KM. The prevalence and risk factors of peripheral neuropathy among patients with type 2 diabetes mellitus; the case of Jordan. Diabetol Metab Syndrome 2018; 10(1): 8-12.

21. Abdissa D, Adugna T, Gerema U, Dereje D. Prevalence of diabetic foot ulcer and associated factors among adult diabetic patients on follow-up clinic at Jimma Medical Center, Southwest Ethiopia, 2019: an institutional-based cross-sectional study. J Diabetes Res 2020; 2020: 4106383.

\begin{tabular}{|c|c|c|c|}
\hline \multicolumn{4}{|c|}{ AUTHORSHIP AND CONTRIBUTION DECLARATION } \\
\hline Sr. \# & Author(s) Full Name & Contribution to the paper & Author(s) Signature \\
\hline 1 & Altaf Ahmad Yar & Data collection. & is \\
\hline 2 & Munaza Javed & Writing of manuscript. & $\left.M_{\text {Mntatat }}\right]$. \\
\hline 3 & Muzamul Shahzad & Statistical analysis. & 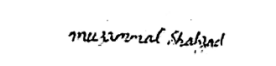 \\
\hline 4 & Javed Iqbal & $\begin{array}{l}\text { Guidance in writing the } \\
\text { manuscript. }\end{array}$ & Junes rearat \\
\hline 5 & Muhammad Imran Aslam & Review of article. & \\
\hline 6 & Zafar Ahmad Khan & Collection of materials. & Zyogrir llow. \\
\hline
\end{tabular}

